\title{
THE POLITICAL ECONOMY OF FOOD STANDARD DETERMINATION: INTERNATIONAL EVIDENCE FROM MAXIMUM RESIDUE LIMITS
}

\author{
Yuan Li, Bo Xiong, John C. Beghin
}

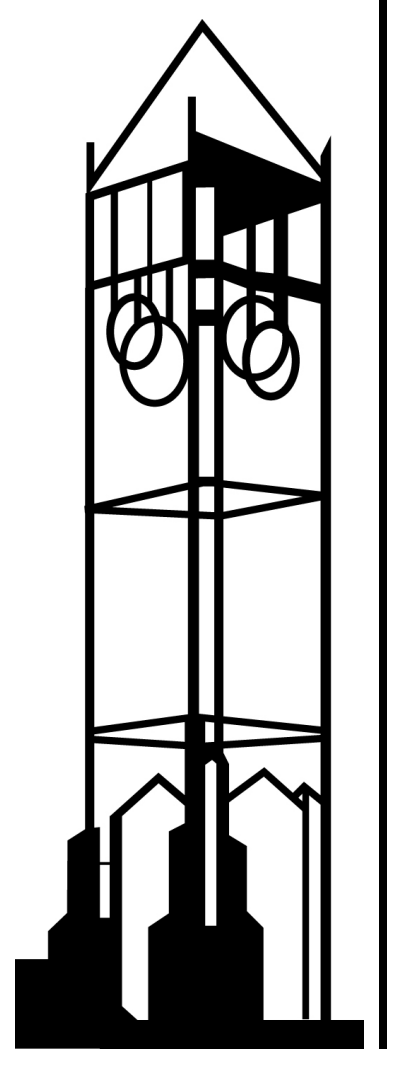

Working Paper No. 13011

May 2013

Revised on July 2014

IOWA STATE UNIVERSITY

Department of Economics

Ames, lowa, 50011-1070 


\title{
The Political Economy of Food Standard Determination: International Evidence from Maximum Residue Limits
}

\author{
Yuan Li, Bo Xiong, and John C. Beghin
}

This version: July 28, 2014

\begin{abstract}
Food safety standards have proliferated as multilateral and bilateral trade agreements constrain traditional barriers to agricultural trade. Stringent food standards can be driven by rising consumer and public concern about food safety and other social objectives, or by the lobbying efforts from domestic industries in agriculture. We investigate the economic and political determinants of the maximum residue limits (MRLs) on pesticides and veterinary drugs. Using a political economy framework and econometric investigation, we find that nations with higher income and larger population adopt stricter MRLs. We also find that countries set more stringent MRLs in their more competitive sectors. Moreover, we show that MRLs and import tariffs are policy substitutes for policy makers. Finally, we find that countries with higher regulatory quality set tougher food standards.
\end{abstract}

Keywords: political economy, food safety, non-tariff measures, maximum residue limits, Codex

JEL codes: Q17, Q18, F13

\footnotetext{
- Yuan Li is a Senior Statistical Consultant at the T-Mobile Inc., Seattle, Washington. Bo Xiong is a postdoctoral researcher at the Agricultural Issues Center, University of California, Davis, California. John Beghin (corresponding author), beghin@iastate.edu, is the Marlin Cole Professor of International Agricultural Economics at the Department of Economics, Iowa State University, Ames, IA. 50011. The authors thank Dermot Hayes, David Hennessy, Ken Koehler, and John Schroeter for discussions and comments on earlier drafts. The authors benefited from the comments of two anonymous reviewers and $A J A E$ editor Brian Roe.
} 


\section{Introduction}

Non-Tariff Measures (NTMs) have proliferated across countries and industries over the past two decades, as tariffs are constrained or eliminated by multilateral or bilateral trade agreements (World Trade Report, 2012). To minimize the impact of NTMs on global trade, member countries of the World Trade Organization (WTO) passed the agreement on the Sanitary and Phyto- Sanitary (SPS) measures and the agreement on the Technical Barriers to Trade (TBT) in 1995. On the one hand, the two agreements encourage member countries to adopt sanitary, phyto-sanitary, and technical measures that are based on the consensus reached on the science underlying them. On the other hand, the two agreements acknowledge members' sovereign rights to ensure or promote food safety, animal welfare, or environmental sustainability (SPS, 1995; TBT, 1995).

The political economy and potential protectionism of NTMs in international trade has been documented and numerous trade disputes have emerged from these frictions. Russia's arbitrary restrictions in fish products have been analyzed by Elvestad and Nilssen (2010); Stanton (2012) provides a review of landmark WTO dispute cases on overly restrictive food safety measures such as the ban on hormone-fed beef and restrictions on genetically modified organisms in the European Union, restrictions on salmon importation by Australia, and restriction on apples by Japan and by Australia among other cases. Pork trade in Australia has also been restricted with protectionist SPS restrictions which were finally lifted in 2004 (Beghin and Melatos, 2012). The United States has not been immune from such restrictive SPS policies as it has been shown in the case for the avocado dispute (Lamb, 2006; Peterson and Orden, 2008), and SPS restrictions on lemon trade (Cororaton and Peterson, 2012). Trade frictions as documented by official SPS concerns reported to the WTO by member countries 
originate in both developed and developing economies (Disdier and van Tongeren, 2010). These reported frictions are especially frequent for raw meat and fish products and fruits and vegetables. Frictions are consistent with several motives such health risk issues, different approaches to risk including precautionary restrictions and stringent policies beyond international food standards, and protectionism. These motives are difficult to sort out.

Are the NTMs more driven by protectionism or legitimate social causes such as risk mitigation in public health? What are the economic, political, and institutional determinants of NTMs? While empirical studies of the political economy of NTMs abound, few attend to disaggregated products with fine measurements of the restrictiveness of NTMs. Ray (1981) investigated the determinants of tariff and NTMs simultaneously for manufacturing industries. The restrictiveness of NTMs was measured categorically, i.e., whether a tariff line is subject to NTMs. Also focusing on the U.S. manufacturing industries, Trefler (1993) jointly estimated the determinants of NTMs and U.S. imports of manufactured goods. The measurement of NTMs was the coverage ratio, or the average number of NTM notifications per tariff line. Using the proportion of imports subject to NTMs as the measurement of NTM stringency, Mansfield and Busch (1995) found that NTMs were used more often in countries with high unemployment levels or appreciated currencies. Using the WTO's NTM notification database, Disdier, Fontagné, and Mimouni (2008) found that NTMs significantly reduced OECD' imports of agricultural products from non-member countries. However, the potential endogeneity of NTM notifications was left unaddressed in their analysis.

In this article, we investigate the political economy of pesticide and veterinary drug regulations. We focus on this set of policies for two reasons. First, the abuse of pesticides and antibiotics in agriculture is among the most alarming food safety issues. For example, in 
January 2014 the scandal involving pesticide-contaminated frozen food resulted in the resignation of the president of one of the largest agri-food companies in Japan. ${ }^{1}$ In December 2013, the Food and Drug Administration of the United States issued new labelling guidelines to address the overuse of antibiotics in agriculture, because of its potential to increase bacterial resistance to antibiotics intended for humans. ${ }^{2}$ Second, the regulatory policy to rein in the abuse of pesticides and veterinary drugs usually takes the form of Maximum Residue Limit (MRL), which sets the maximum admissible rate of concentration (measured in parts per million or parts per billion) for a certain substance residue in a specific product. The numerical nature of MRLs allows a direct quantitative measurement of the regulatory stringency.

We contribute to the understanding of food safety policy formation in two important ways. First, we propose a conceptual model to characterize policy makers' joint decision on tariffs and food safety standards. Our model highlights the similarities and dissimilarities between the two policy instruments and provides a baseline for empirical analysis. Second, we develop an econometric specification consistent with the model to explain the formation of MRLs affecting pesticides and veterinary drugs residues for 253 commodities and 53 countries. Our article is the first one in the political economy literature that formally investigates the determinants of food safety standards at a disaggregated product level and for a wide range of countries.

We find that nations with higher income and larger population adopt stricter MRLs. We also find that countries set more stringent MRLs in their more competitive sectors. Moreover, we show that MRLs and import tariffs are substituting instruments for policy

\footnotetext{
${ }^{1}$ See the coverage from Nikkei Asian Review at http://asia.nikkei.com/Business/Trends/Frozen-food-industrymust-put-house-in-order.

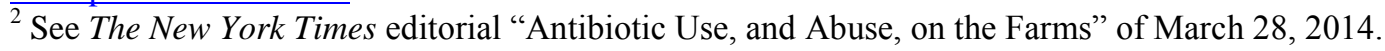


makers. In addition, we find that countries with higher regulatory quality set tougher food standards. Our results are useful to policy makers and trade representatives engaged in regional and multilateral trade negotiations in which the balance between an open global economy and other social objectives is of key importance.

The rest of the article is organized as follows. In Section 2 we introduce a simple political economy framework to characterize policy makers' optimal choices of tariffs and food safety standards. In Section 3 we derive an empirical specification from the conceptual model, followed by descriptions of data and discussions of regression results. We draw conclusions and policy implications in Section 4.

\section{The political economy framework}

\subsection{The policy maker's problem}

Unsafe food poses risk to public health and the ecosystem in general. Such social costs can be ignored by discounted by private markets, which calls for policy makers to set public food standards. However, influenced by lobbying efforts of domestic industries, policy makers may set excessive food safety standards to keep out foreign competition. Several conceptual models emerge from the literature to address the political economy of food safety standards. Fisher and Serra (2000) show that a domestic social planner always sets these standards above the level that maximizes the global welfare. Marette and Beghin (2010) find that policy makers may also prescribe overly low food safety standards if domestic producers are at a comparative disadvantage in compliance. Swinnen and Vandemoortele (2009) argue that policy makers generally set food safety standards more stringent than other food quality standards (e.g., nutrition contents) because of the risk to public health.

The policy formation of food safety standards is inseparably from that of import 
tariffs. From the viewpoint of a policy maker, standards-setting and border-taxing are two instruments to strike a balance between the interest of constituents, the interest of domestic industries, and the fiscal contribution of custom duties. Although the interaction of tariff and non-tariff measures is well understood, theoretical characterizations of policy makers' joint decision-making are few. We provide a general political economy framework to underscore the similarities and dissimilarities between standards-setting and tariff-setting.

We describe the policy maker's problem in a small open economy using the political support function approach. ${ }^{3}$ Specifically, the policy maker chooses a specific duty $\tau$ and a level of food safety standard $\lambda$ (with larger $\lambda$ indicating more stringency) to maximize the objective function $W$

$$
W(\tau, \lambda)=\alpha[C S(p)-E C(\lambda, D(p))]+\beta P S^{d}(p, c)+\gamma \tau\left[D(p)-S^{d}(p, c)\right]
$$

where $\alpha+\beta+\gamma=1, p=w p(\lambda)+\tau$, and $c=c(\lambda)$. Note that $\alpha, \beta$, and $\gamma$ are the weights the policy maker assigns to constituents, domestic industries, and custom revenues. The function CS(.) is the consumer surplus function, which decreases in the market price $p .{ }^{4}$ In a small open economy, the market price $p$ exceeds the world price $w p$ (which increases in the level of standards in the destination market) by the specific duty $\tau .{ }^{5}$ Function $E C(\cdot)$ measures the social cost of negative externality in food consumption associated with unsafe food. ${ }^{6}$ This cost decreases in the level of standards $\lambda$ but increases in the level of total food consumption. The function $D(\cdot)$ is the Marshallian demand function governed by the same preferences as the

\footnotetext{
${ }^{3}$ See Hillman (2013) for a review of the political support function approach. See de Gorter and Swinnen (2002) for a survey of the applications to agricultural policies.

${ }^{4}$ For brevity, other determinants of demand (e.g., income, taste, and abundance of substitutes) are omitted from the conceptual model but included in the empirical application.

${ }^{5}$ Alternatively, the import tariff can be modeled as an ad valorem rate. We choose the specific duty approach to simplify the characterization of the optimal tariff rate.

${ }^{6}$ As in Fisher and Serra (2000) and Marette and Beghin (2010), we assume that the externality is additively separable from the consumption utility.
} 
function $C S(\cdot)$.

The function $P S^{d}(p, c)$ is the domestic industry's producer surplus that increases in the market price but decreases in a compliance cost parameter $c$, which implicitly depends on the level of standards in the home market. The function $S^{d}(p, c)$ is the domestic supply function governed by the same cost structure as the function $\operatorname{PS}^{d}(p, c)$. Finally, custom revenues are the product of the specific duty $\tau$ and the quantity of imports $\left(D-S^{d}\right)$.

\subsection{The optimal choice of tariffs and food safety standard}

The policy maker's joint decision on tariffs and standard stringency is characterized by the two first-order conditions resulted from the maximization of (1). Specifically, the first-order condition governing the optimal tariff is

(2) $\alpha\left(C S^{\prime}-E C_{2} D^{\prime}\right)+\beta S^{d}+\gamma\left[D-S^{d}+\tau\left(D^{\prime}-S_{1}^{d}\right)\right]=0$,

where $E C_{i}$ is the partial derivative of the external cost function with respect to its $i$-th argument. ${ }^{7}$ Intuitively, equation (2) states that a higher tariff rate has three effects. First, it reduces constituents' consumption utility $\left(C S^{\prime}<0\right)$ but mitigates the negative externality ( $E C_{2}>0$ and $\left.D^{\prime}<0\right)$. Second, a higher duty rate benefits domestic producers by shielding them from foreign competition. Third, a higher tariff rate raises the per-unit revenue but reduces the tax base at customs. At the political economy optimum, the tariff is set at a level where these marginal benefits and costs cancel out.

The optimal level of standard stringency is governed by the following first-order condition:

$$
\alpha\left(C S^{\prime}-E C_{2} D^{\prime}\right) w p^{\prime}-\alpha E C_{1}+\beta\left(S^{d} w p^{\prime}+P S_{2}^{d} c^{\prime}\right)+\gamma \tau\left[\left(D^{\prime}-S_{1}^{d}\right) w p^{\prime}-S_{2}^{d} c^{\prime}\right]=0,
$$

\footnotetext{
${ }^{7}$ Note that we use the envelope theorem $\partial P S^{d} / \partial p=S^{d}$ in the derivation of (2).
} 
where $P S_{2}^{d}$ is the partial derivative of domestic producer surplus with respect to the cost parameter, $S_{i}^{d}$ is the partial derivative of the domestic supply with respect to its $i$-th argument. Intuitively, equation (3) says that a more stringent food safety standard reduces the consumption utility $\left(C S^{\prime}<0\right)$ but mitigates the external cost because quantity consumed falls $\left(E C_{2}>0\right.$ and $\left.D^{\prime}<0\right)$ and the risk per unit of consumption is abated $\left(E C_{1}<0\right)$.

On the supply side, tougher food safety standards raise the costs faced by both foreign competitors $\left(w p^{\prime}>0\right)$ and domestic industries $\left(P S_{2}^{d}<0, c^{\prime}>0\right)$. Therefore, the net effect on the domestic producer surplus is ambiguous, hinging on whether domestic industries have comparative advantages in compliance with the standard. Finally, more a stringent food safety standard can affect the quantity of import in either direction. The key determinant is also the comparative advantage of domestic industries over foreign competitors in compliance.

The political economy optimal tariffs and food safety standard are implicitly defined by the system of equations (2) and (3). It is worth noting that the two equations have several components in common. ${ }^{8}$ In fact, all shared elements involve the impacts of price changes. The marginal effect of a specific duty directly translates into the marginal effect of the market price. Equation (2) says that the optimal political economy tariff is set such that the marginal impact of a price change on the political economy is null. Consequently, we simplify the characterization of the political economy optimal standard by substituting (2) into (3) to get (4) $-\alpha E C_{1}+\beta P S_{2}^{d} c^{\prime}+\gamma\left[-\tau S_{2}^{d} c^{\prime}-\left(D-S^{d}\right) w p^{\prime}\right]=0$.

The political economy optimal level of the food safety standard, $\lambda^{*}$, is implicitly defined by equation (4), that is,

\footnotetext{
${ }^{8}$ See Swinnen, Olper, and Vandemoortele (2011) for a systematic investigation of the interaction between different types of policy instruments, ranging from border taxations to domestic farm legislations and how these are conditioned by quality of institutions and the importance of tax revenue motives.
} 
(5) $\lambda^{*}=f\left(\alpha, \beta, \gamma ; E C_{1} ; P S_{2}^{d}, c^{\prime}, S_{2}^{d} ; \tau, M, w p^{\prime}\right)$,

with imports $M=D-S^{d}$. Intuitively, equation (5) states that the political economy optimal standard is determined by the political weights and influence, risk mitigation per unit of consumption, production and compliance costs for domestic industries, current tariff rate, current import volume, and the compliance cost for foreign producers. Therefore, equation (5) provides a guideline for empirical investigations, which we pursue next.

\section{The empirical application to MRLs}

In this section we investigate the economic, political, and institutional determinants of the MRLs on insecticides and antibiotic drugs. First, we specify a regression equation based on equation (5) in the previous section. Second, we describe the MRL data and the explanatory variables. Third, we present the econometric results and discuss the policy implications. Finally, we check the sensitivity of the results with respect to commodity groups and omitted national characteristics.

\subsection{The empirical approach}

\subsubsection{The model specification}

To implement equation (5) empirically, we classify the determinants of the food safety standards into three categories: demand-side factors, supply-side factors, and political or institutional factors. The demand-side category contains the risk mitigation per unit of consumption $\left(E C_{1}\right)$. The magnitude of this risk mitigation effect depends on the product characteristics, the total consumption quantity, which is derived from consumers' preference, income, and socio-demographical variables. The supply-side category includes the production and compliance costs faced by domestic industries $\left(P S_{2}^{d}, S_{2}^{d}\right.$, and $\left.c^{\prime}\right)$, the compliance cost faced by foreign competitors $\left(w p^{\prime}\right)$, and the quantity of import $(M)$. The political and 
institutional category includes the endogenous tariff rate $(\tau)$, and political weights assigned to voters-consumers, special supply interest, and fiscal considerations $(\alpha, \beta$, and $\gamma)$.

Since our empirical application involves multiple products, we normalize the supplyside factors in equation (5) by the supply conditions in the rest of the world. In particular, we use the comparative advantages of domestic industries to control for the competitiveness. Furthermore, we include import penetration rate to measure the each sector's dependency on the global market. Therefore, we propose the following specification based on equation (5):

(6) $\lambda_{j k}^{*}=\phi_{k}+\phi^{e} E_{j k}+\phi^{i} I_{j}+\phi^{n} N_{j}+\phi^{c a} C A_{j k}+\phi^{i p} I P_{j k}+\phi^{\tau} T_{j k}+\sum_{l} \phi^{l} Z_{j}^{l}$,

where $j$ and $k$ are country and product indices, and $\phi \mathrm{s}$ are parameters to be estimated. Note that the product-specific intercept controls for product characteristics such as risk per unit of consumption. The determinants of the standard in equation (6) include the price elasticity of demand for the product in each country $E_{j k}$, the level of income $I_{j}$, the population of the nation $N_{j}$, the comparative advantage of the domestic industry $C A_{j k}$, the import penetration rate in the country and industry of interest $I P_{j k}$, the current rate of import tariff $T_{j k}$, and other macroeconomic, political, and institutional characteristics $Z_{j}^{l}$ at the country level.

\subsubsection{The estimation procedure}

Because policy makers decide on the import duties and standards simultaneously, the tariff rate in (6) is subject to endogeneity. We use the instrumental approach to address the problem. In particular, we take advantage of the fact that the applied tariff rates in each country cannot be higher than the bound duty rates in the trade agreements to which the country has committed. The bound duty rates result from past multilateral trade agreements and therefore exogenous to the policy-making processes in individual countries. Consequently, we can 
estimate equation (6) using the 2-stage least square procedure, with the bound duty rates as instrumental variables for applied tariff rates. ${ }^{9}$

\subsection{The data}

\subsubsection{The measurement of MRL stringency}

The global MRL database, available from the Foreign Agricultural Service (FAS), United States Department of Agriculture (USDA), contains the currently effective MRLs on pesticides and veterinary drugs across a wide range of products and countries (USDA-FAS). Each MRL addresses a specific substance (i.e., pesticide or drug type) in a specific commodity in a specific country (including Codex in the set of countries). Using these MRLs as of April 2012, Li and Beghin (2014) constructed the following MRL stringency index at the country and product level:

(7) $M R L_{j k}=\frac{1}{N_{(k)}} \sum_{n_{(k)}=1}^{N_{(k)}} \exp \left(\frac{M R L_{c o d e x, k n_{(k)}}-M R L_{j k n_{(k)}}}{M R L_{c o d e x, k n_{(k)}}}\right)$,

where $M R L_{j k n_{(k)}}$ is the MRL set by country $j$, for product $k$, and targeting substance $n_{(k)}$;

$M R L_{c o d e x, k n_{(k)}}$ is the MRL recommended by Codex for the same product and substance

combination; and $N_{(k)}$ is the number of substances applicable to product $k$.

Intuitively, equation (7) states at the MRL stringency towards a certain product in a certain country is an average stringency over MRLs targeting all relevant substances used in producing the product and with each individual MRL referenced to its Codex counterpart in percent deviation from Codex. The MRL stringency score has three practical merits. ${ }^{10}$ First, the reference to the Codex MRLs accommodates the scientific fact that some pesticides or

\footnotetext{
${ }^{9}$ To accommodate the few unbound duty rates, we apply the normal distribution function to all bound rates and assign the value unity (the upper limit of a probabilistic distribution) when tariffs are unconstrained.

${ }^{10} \mathrm{See} \mathrm{Li}$ and Beghin (2014) for more discussions of the properties of the stringency scores. See Xiong and Beghin (2014) for an assessment of the trade effects of the MRLs in pesticides.
} 
veterinary drugs pose greater risks than others. Second, the measurement of the MRL stringency increases in individual MRLs. In particular, unity serves as a useful benchmark for equation (7): a score above (or below) one indicates that the MRL regulation is more (or less) restrictive than Codex. Third, the exponential transformation expresses the convexity of the cost of complying with stringency much beyond the Codex recommendations, which could become very steep. This is consistent with the fact the SPS and TBT agreements encourage WTO member countries to harmonize MRLs towards the Codex levels to avoid such cost.

We use the MRL stringency scores from Li and Beghin (2014) for 253 products in 53 countries as the measurement of food safety standards. ${ }^{11}$ Our country coverage is broader that most of the previous studies (e.g., Anderson, Rausser, and Swinnen, 2013; Swinnen, Olper, and Vandemoortele, 2012). In particular, we include many less and least developed nations that are absent in the previous studies. ${ }^{12}$ The products under investigation are also more disaggregated (at either 4 or 6 digit level in the Harmonized System classification) than in the recent literature. ${ }^{13}$ As of 2013 , the products and countries of interest account for more than $90 \%$ of the world agricultural trade. We use Figure 1 to illustrate the cross-region discrepancy in MRL policies. In particular, we find that advanced economies tend to adopt MRLs that are more stringent than the Codex recommendations, while developing countries often use less restrictive policies. Stringency in the EU block in particular stands out. In NAFTA, Canada has kept more stringent MRLs than the US, and Mexico has aligned its MRL on the US.

\section{[Insert Figure 1 here]}

\subsubsection{The determinants of MRLs}

\footnotetext{
${ }^{11}$ Since the European Parliament sets the MRLs in the European Union, we use an aggregate EU entity to represent all 28 member nations.

${ }^{12}$ See Table A in Appendix A for the list of countries.

${ }^{13}$ See Table B in Appendix B for the list of products.
} 
All determinants of MRLs are measured as of 2011unless noted otherwise. The elasticity of demand for a product hinges on the number of substituting goods. We use the number of commodities within the same tariff line to approximate the responsiveness of demand to price changes. ${ }^{14}$ To control for the market size, we use per-capita income data and population estimates from the World Bank Indicators. In particular, we measure the per-capita income on the basis of purchasing power parity in order to adjust for price differences across countries. To measure the competitiveness of a given industry in a given country, we obtain the Revealed Comparative Advantage (RCA) using data from the COMTRADE database of the United Nations. Specifically, the RCA is computed as the export share of the product in the country's total export, divided by the export share of the same product in the total exports of the rest of the world (Balassa, 1965). We also use the effectively applied tariff rates and bounded tariff rates from the TRAINS database.

We now consider several macroeconomic, political, and institutional factors that potentially affect the formation of MRLs. A country's macroeconomic policy impacts the competitiveness of its agricultural sector through influencing the terms of trade. We use the real exchange rate from Heston et al. (2009) to control for the effect of macroeconomic policies.

We also consider two political factors in the standards-setting process. First, the effectiveness of lobbying efforts from industry groups hinges on the political spectrum within the legislative branch of government. A more diverse body of law makers makes lobbying more costly but also makes policy reforms less likely. To control for the differences in legislative organizations, we use the legislative index of electoral competitiveness (LIEC)

\footnotetext{
${ }^{14}$ Formal estimates of demand elasticities for the products and countries of interest are non-existent in the literature.
} 
from the Database of Political Institutions 2010 of the World Bank. The LIEC accounts for the number of candidates within a party and the dominance of the largest party in legislature. Second, political stability affects policy makers' perspective on short-term versus long-term objectives. A more stable regime makes systemic reforms of public policies more likely. We measure political stability by the number of years a country is in an autocratic or democratic status, available from the Database of Political Institutions 2010 of the World Bank.

Finally, we consider two institutional factors that vary significantly across countries.

First, the implementation cost of food safety standards is much higher than that of traditional trade barriers. Therefore, governments with poorer regulatory quality are less likely to resort to food safety standards. We use the regulatory quality index from the World Bank as a measurement of the efficiency of government. Second, socio- demographics in rural areas plays an important role in farm-related policies and possibly permeates the formation of food safety standards. We use the ratio of farm employment over farm land from the World Bank as the measurement in our empirical investigation.

\subsection{The benchmark results}

We present the results from the 2-stage least square procedure in Table 1 . We discuss the formation of MRLs first. We find that applied import tariffs and MRLs are policy substitutes for policy makers. This result suggests that policy makers adopt stringent MRLs to shield domestic industries from international competition as import duties are constrained and reduced by various trade agreements. The response of the MRL to the tariff is strong (an elasticity of -5.45 at the mean of the dataset). This is the strongest response of the MRL to variation in its political economy determinants. 
Table 1. The political economy of MRLs, with endogenous applied tariff rates

\begin{tabular}{|c|c|c|c|}
\hline \multirow[t]{2}{*}{ Variables } & \multicolumn{2}{|c|}{$\begin{array}{l}\text { MRL stringency score equation } \\
\qquad 2^{\text {nd }} \text { stage }\end{array}$} & \multirow{2}{*}{$\begin{array}{l}\text { Tariff equation } \\
\frac{1^{\text {st }} \text { stage }}{\text { Coefficient }}\end{array}$} \\
\hline & Coefficient & $\begin{array}{l}\text { MRL elasticity } \\
\text { wrt determinant }\end{array}$ & \\
\hline Applied tariff rate & $\begin{array}{l}-0.417 \\
(0.055)\end{array}$ & -5.453 & N.A. \\
\hline Bound tariff rate* & n.a. & n.a. & $\begin{array}{c}0.392 \\
(0.014)\end{array}$ \\
\hline Log of real per-capita GDP & $\begin{array}{c}0.113 \\
(0.007)\end{array}$ & 0.105 & $\begin{array}{c}0.032 \\
(0.004)\end{array}$ \\
\hline Log of population & $\begin{array}{c}0.060 \\
(0.003)\end{array}$ & 0.056 & $\begin{array}{l}-0.030 \\
(0.002)\end{array}$ \\
\hline Log of real exchange rate & $\begin{array}{l}-0.004 \\
(0.002)\end{array}$ & -0.004 & $\begin{array}{c}0.007 \\
(0.001)\end{array}$ \\
\hline $\begin{array}{l}\text { Log of the number of products } \\
\text { within the same tariff line }\end{array}$ & $\begin{array}{c}0.007 \\
(0.003)\end{array}$ & 0.006 & $\begin{array}{c}0.007 \\
(0.002)\end{array}$ \\
\hline $\begin{array}{l}\text { Number of regional trade } \\
\text { agreements }\end{array}$ & $\begin{array}{l}-0.033 \\
(0.002)\end{array}$ & -1.150 & $\begin{array}{c}0.012 \\
(0.001)\end{array}$ \\
\hline $\begin{array}{l}\text { Log of the Revealed } \\
\text { Comparative Advantage }\end{array}$ & $\begin{array}{l}-0.007 \\
(0.001)\end{array}$ & -0.006 & $\begin{array}{c}0.000 \\
(0.001)\end{array}$ \\
\hline Log of Ag import penetration & $\begin{array}{l}-0.018 \\
(0.005)\end{array}$ & -0.017 & $\begin{array}{l}-0.049 \\
(0.003)\end{array}$ \\
\hline $\begin{array}{l}\text { Log of the longevity of the } \\
\text { regime }\end{array}$ & $\begin{array}{l}-0.027 \\
(0.004)\end{array}$ & -0.025 & $\begin{array}{l}-0.016 \\
(0.003)\end{array}$ \\
\hline Regulatory quality & $\begin{array}{c}0.067 \\
(0.007)\end{array}$ & 0.018 & $\begin{array}{l}-0.015 \\
(0.004)\end{array}$ \\
\hline Ag labor/land ratio & $\begin{array}{l}-0.000 \\
(0.002)\end{array}$ & -0.000 & $\begin{array}{c}0.016 \\
(0.002)\end{array}$ \\
\hline $\begin{array}{l}\text { Legislative competitiveness } \\
\text { dummy } 1^{* *}\end{array}$ & $\begin{array}{l}-0.377 \\
(0.026)\end{array}$ & -0.350 & $\begin{array}{l}-0.051 \\
(0.016)\end{array}$ \\
\hline $\begin{array}{l}\text { Legislative competitiveness } \\
\text { dummy } 2 * *\end{array}$ & $\begin{array}{l}-0.366 \\
(0.021)\end{array}$ & -0.340 & $\begin{array}{c}0.037 \\
(0.013)\end{array}$ \\
\hline
\end{tabular}




\begin{tabular}{lccc} 
Legislative competitiveness & 0.026 & 0.024 & -0.065 \\
dummy 3** & $(0.021)$ & & $(0.013)$ \\
& 0.034 & 0.032 & 0.122 \\
$\begin{array}{l}\text { Legislative competitiveness } \\
\text { dummy 4** }\end{array}$ & $(0.016)$ & & $(0.010)$ \\
$\mathrm{R}^{2}$ & 0.17 & n.a. & 0.17 \\
\hline
\end{tabular}

Note: *Denotes the instrumental variable for the applied tariff rate. The Hausman-Durbin-Wu test rejects the exogeneity of applied tariff rate at $1 \%$ significance level. Product dummy variables are included in both stages of the estimation. **The elasticity is the percent change in the MRL score for a score regulated in each of the 4 legislative regimes relative to the most competitive legislative regime subsumed in the intercept.

Next, we find that countries with higher per-capita income adopt more stringent MRLs. This is because the public's awareness of food safety, animal welfare, and environmental sustainability tends to rise with the income level. The income elasticity of the MRL is 0.10 at the mean of the dataset. The result suggests that the policy formation of MRLs is partly driven by legitimate social objectives. We also find that more populous nations tend to implement more stringent MRLs. The elasticity is not as large as for income, at 0.06 . This population response suggests that public health has more at stake in a nation with more residents; food demand is larger and the potential externality is larger as well.

Furthermore, countries with weaker currencies use less restrictive MRLs, but this result is barely statistically significant and the elasticity is very small and is dwarfed by other determinants. In addition, we find that countries adopt more stringent MRLs in sectors where the demands for the products are more sensitive to price changes but this effect is moderate, with an elasticity of 0.01 at the mean. This result can be rationalized with compliance costs of MRLs being passed on to consumers to a lesser degree in a market where the demand is more elastic. Finally we find that countries committed to more regional trade agreements use less stringent MRLs. This finding indicates the effectiveness of regional trade agreements in bringing moderation in setting food safety and other NTMs. This effect is quite strong with 
an elasticity of -1.15 .

Next we discuss the political factors underlying the formation of MRLs. Countries adopt less stringent MRLs in sectors where the domestic producers are more competitive in the world market. The estimated effect is small (elasticity of -0.01). Lobbying efforts and political donations tend to decrease with international competitiveness. Countries more dependent on agricultural imports tend to implement less restrictive MRLs. But again this effect is moderate (elasticity of -0.02). In addition, more entrenched regimes use moderately less restrictive MRLs (elasticity of -0.03).

Finally, we address the institutional determinants of MRLs. Governments with better regulatory quality implement slightly tougher MRLs (elasticity of 0.02). The design and enforcement of MRLs require expertise from technocrats and coordination among different bodies of the government. Therefore, administrative costs of MRLs are relatively lower in governments with higher regulatory quality. This result is consistent with the analytical results of Swinnen et al. (2011) on the impact of institutional capacity of countries on policy choices. Regarding the competitiveness of the legislative branch of government, competition among law makers leads to more stringent MRLs in agriculture. This can be seen by comparing the sizeable negative fixed effects of dummy 1 and dummy 2 with the small positive fixed effects of dummy 3 and dummy 4 relative to the most competitive legislative regime (the omitted category among the 5). More backward political systems (regime dummy 1 and 2) may hinder policy debate and regulatory effort to protect public health which can be done in more competitive legislative regimes (the other 3 categories). There is a slight inverted $U$ shape effect as regimes 3 and 4 are characterized by slightly higher MRL scores than the most competitive legislative regime subsumed in the intercept. A similar 
finding on farm income support was reported by Beghin and Kherallah (1994).

Next, we discuss the results from the tariff equation, or the first-stage estimation in Table 1. Using the Hausman-Durbin-Wu test, we reject the null hypothesis that the applied tariff rate is exogenous to MRLs. This test result suggests that policy makers choose the import duties and MRLs simultaneously.

In terms of the tariff determinants, we find that bound tariff rates act as strong binding constraint on the applied duty rates. Regarding the economic determinants of applied tariffs, richer and less populous countries protect domestic agricultural markets to a larger degree. This is possibly because agricultural industries in those countries are better organized and execute more lobbying efforts. We also find that nations with weaker currencies impose higher tariffs. Moreover, we find that heavier duties are imposed on sectors where the demands for the products are more sensitive to price changes. The reason is that border duties are less reflected in market prices in those sectors. Unexpectedly, applied tariff rates are higher in countries that are engaged in more regional trade agreements, other things being equal. However, as we have seen above, countries committed to more regional trade pacts adopt less restrictive MRLs and also have presumably lower bound tariffs through their RTA commitments. The result here captures the small "anti-liberalization" effect through applied tariff but conditioned on bound tariffs commitments and moderation in MRLs.

Regarding political and institutional determinants of import tariffs, we find that the comparative advantage at the product level has negligible impacts on the tariff rate. One possible reason is that different growing and marketing seasons of fresh plant products attenuate the competition between domestic and foreign industries in agriculture. For possibly similar reasons, we find that countries more dependent on agricultural imports tend 
to levy lower tariffs. We also find that import duties are lower in countries with higher political stability and better regulatory quality. One possible reason is that market liberalization is more likely to happen in those regimes. Furthermore, we find that countries with higher agricultural labor-to-land ratio impose higher import duties. This is possibly because protectionism in agriculture is more essential to social stability when more farmers tend to be small-scaled and unproductive due to the lack of capital or technological resources. Finally, we find that the degree of competition within the legislative branch of the government does not affect the degree of tariff liberalization monotonically.

\subsection{The sensitivity analysis}

In this subsection we provide two robustness checks for our empirical results and investigate the formation of MRLs in more detail.

\subsubsection{The difference between pesticides and antibiotics regulations}

In the first sensitivity analysis, we distinguish the MRLs on veterinary drugs applied to animal products from those on pesticides applied to plant products. The two types of MRLs address two kinds of social hazards: regulations on veterinary drugs mitigate the risks directly posed to animals and indirectly posed to human health in the long run; regulations on pesticides address the sanitary risks of human consumption of plant products. To discern the two policy objectives, we re-estimate equation (6) with the sub-sample consisting of MRLs regulating veterinary drugs only. The sub-sample contains 941 observations, or $8 \%$ of all observations. ${ }^{15}$ We report the associated results in Table 2. Results using the much larger subset of products with pesticides MRLs only are nearly identical to those shown in Table 1 and are not reproduced here.

\footnotetext{
${ }^{15}$ The corresponding animal products belong to three HS chapters: 2, 4, and 15. See Appendix A for product descriptions.
} 
Table 2. The political economy of MRLs targeting veterinary drugs

\begin{tabular}{|c|c|c|c|}
\hline Applied tariff rate & $\begin{array}{c}0.411 \\
(0.215)\end{array}$ & $\begin{array}{l}\text { Log of the longevity of the } \\
\text { regime }\end{array}$ & $\begin{array}{l}-0.005 \\
(0.013)\end{array}$ \\
\hline Log of real per-capita GDP & $\begin{array}{c}0.085 \\
(0.018)\end{array}$ & Regulatory quality & $\begin{array}{c}0.046 \\
(0.018)\end{array}$ \\
\hline Log of population & $\begin{array}{c}0.060 \\
(0.003)\end{array}$ & Ag labor/land ratio & $\begin{array}{c}0.001 \\
(0.007)\end{array}$ \\
\hline Log of real exchange rate & $\begin{array}{l}-0.002 \\
(0.007)\end{array}$ & $\begin{array}{l}\text { Legislative competitiveness } \\
\text { dummy } 1\end{array}$ & $\begin{array}{l}-0.125 \\
(0.065)\end{array}$ \\
\hline $\begin{array}{l}\text { Log of the number of products } \\
\text { within the same tariff line }\end{array}$ & $\begin{array}{c}0.003 \\
(0.009)\end{array}$ & $\begin{array}{l}\text { Legislative competitiveness } \\
\text { dummy } 2\end{array}$ & $\begin{array}{l}-0.145 \\
(0.053)\end{array}$ \\
\hline $\begin{array}{l}\text { Number of regional trade } \\
\text { agreements }\end{array}$ & $\begin{array}{l}-0.022 \\
(0.005)\end{array}$ & $\begin{array}{l}\text { Legislative competitiveness } \\
\text { dummy } 3\end{array}$ & $\begin{array}{l}0.095 \\
(0.061)\end{array}$ \\
\hline $\begin{array}{l}\text { Log of the Revealed } \\
\text { Comparative Advantage }\end{array}$ & $\begin{array}{l}-0.001 \\
(0.005)\end{array}$ & $\begin{array}{l}\text { Legislative competitiveness } \\
\text { dummy } 4\end{array}$ & $\begin{array}{c}0.033 \\
(0.041)\end{array}$ \\
\hline Log of Ag import penetration & $\begin{array}{l}-0.009 \\
(0.012)\end{array}$ & $\mathrm{R}^{2}$ & 0.11 \\
\hline
\end{tabular}

Note: Bound tariff rate is used as the instrumental variable for the applied tariff rate. Product dummy variables are included in both stages of the estimation. The first-stage estimation is omitted for brevity.

As shown in Table 2, we find that impact of the applied tariffs on MRLs has become not statistically significant at the $5 \%$ confidence level and that the sign of the impact has changed. This finding suggests that the MRLs on antibiotics are less driven by protectionism than those on pesticides. We also find that the income effect is less pronounced than in Table 1, which indicates that sanitary risks are more of a concern than sanitary risks in high-income countries. Other results are qualitatively similar to the benchmark findings.

\subsubsection{Accounting for unobservable national characteristics}

In the second robustness check, we address the potential biases due to the omission of unobservable country-level characteristics. Some economic, political, or institutional factors are unmeasurable but possibly contribute to the political design of tariffs and MRLs. To 
address this concern, we conduct an augmented 2SLS regression in which we include the countries' fixed effects in both stages. As a practical matter, the presence of country-specific fixed effects makes the income, population, and other country-level explanatory variables redundant. That is, we rely solely on the cross-product variations to identify the empirical model. We report the associated results in Table 3.

Table 3. The political economy of MRLs, with countries' fixed effects

\begin{tabular}{lclc}
\hline Applied tariff rate & $\begin{array}{l}-0.264 \\
(0.068)\end{array}$ & $\begin{array}{l}\text { Log of the Revealed } \\
\text { Comparative Advantage }\end{array}$ & $\begin{array}{c}-0.002 \\
(0.001)\end{array}$ \\
$\begin{array}{lcll}\text { Number of number of products } \\
\text { within the same tariff line }\end{array}$ & $\begin{array}{l}0.015 \\
(0.003)\end{array}$ & $\mathrm{R}^{2}$ & 0.61 \\
\hline Note: Bound tariff rate is used the instrumtal & & \\
\hline
\end{tabular}

Note: Bound tariff rate is used as the instrumental variable for the applied tariff rate. Products' and countries' dummy variables are included in both stages of the estimation. The first-stage estimation is omitted for brevity.

As shown in Table 3, we are able to identify the impacts of three determinants that vary across products. First, we reinforce our benchmark result that tariffs and MRLs are used by policy makers as substituting policy instruments. Second, we re-affirm that more stringent MRLs are adopted in products for which consumers' demands are more sensitive to price changes. Third, we find weak evidence that countries impose less restrictive MRLs in their more competitive sectors.

\section{Conclusions}

The political economy and determination of food safety standards are of great importance as trade integration and globalization deepen on one hand and the public's demand for social objectives rises on the other. We contribute to the understanding of the policy formation of food safety standards in two ways. First, we provide a conceptual framework to characterize policy maker's joint decision on import duties and food safety standards, which address the negative externality of food consumption. The proposed conceptual model provides a guideline for empirical investigations of food safety standards, or non-tariff measures in 
general. Second, in a case study of MRLs on pesticides and veterinary drugs regulating food in a large set of countries, we illustrate the roles of economic, political, and institutional factors in the formation of food safety standards. In particular, we find that nations with higher income and larger population adopt stricter food safety standards. We also find that countries set more stringent MRLs in their more competitive sectors. Moreover, we document that policy makers use MRLs and tariffs as substitute policy instruments and that the substitution is high.

Future research in the political economy of food safety standards can be pursued along several dimensions. First, panel data with time variation in the MRLs would allow better quantification of the economic, political, and institutional determinants. Second, interdisciplinary collaboration is needed to gauge the size the social benefits of tightening food safety standards. Third, private food standards used by private food processors and retailers often exceed their public counterparts and the relationship between the determination of public and private food standards is worth exploring. 


\section{References}

Anderson, K., G.C. Rausser, and J.F.M. Swinnen. 2013. "Political Economy of Public Policies: Insights from Distortions to Agricultural and Food Markets." Journal of Economic Literature, 51(2): 423-77.

Balassa, B. 1965. "Trade liberalization and 'revealed' comparative advantage", The Manchester School of Economic and Social Studies 33: 92-123

Beghin, J. C. and M. Kherallah. 1994. "Political Institutions and International Patterns of Agricultural Protection" The Review of Economics and Statistics 76(3): 482-489.

Beghin, J.C., and M. Melatos. "The Trade and Welfare Impacts of Australian Quarantine Policies: The Case of Pigmeat." The World Economy 35.8 (2012): 1006-1021.

Beck, T., G. Clarke, A. Groff, P. Keefer, and P. Walsh. 2001. "New tools in comparative political economy: The Database of Political Institutions." World Bank Economic Review. 15(1): 165-17.

Cororaton, C. B., and E. B. Peterson. "Potential of Regional and Seasonal Requirements in US Regulation of Fresh Lemon Imports." The World Economy 35.8 (2012): 1022-1036.

de Gorter, H. and J.F.M. Swinnen. 2002. "Political economy of agricultural policy" in , in: B. L. Gardner \& G. C. Rausser (ed.), Handbook of Agricultural Economics, edition 1, volume 2, chapter 36: 1893-1943. Elsevier. North Holland.

Disdier, A-C, and F. van Tongeren. "Non-tariff measures in agri-food trade: What do the data tell us? Evidence from a cluster analysis on OECD imports." Applied Economic Perspectives and Policy 32 (3) (2010): 436-455.

Disdier, A-C., L. Fontagné, and M. Mimouni. 2008. « The impact of regulations on agricultural trade: evidence from the SPS and TBT agreements." American Journal of 
Agricultural Economics 90(2): 336-350.

Elvestad, C., and F. Nilssen. 2010. "Restricting imports to the Russian food market: simply an act of protectionism?" Post-Communist Economies 22.3: 267-282.

Fischer, R., and P. Serra. 2000. "Standards and Protection," Journal of International Economics 52: 377-400.

Grossman, G.M., and E. Helpman. 1994. "Protection for sale", The American Economic Review 84: 833-850.

Heston, A., R. Summers and B. Aten. 2009. Penn World Table Version 6.3, Center for International Comparisons of Production, Income and Prices at the University of Pennsylvania, August.

Hillman, A. L. 2013. The political economy of protection. Taylor \& Francis.

Lamb, R. L. 2006. "Rent seeking in US-Mexican avocado trade." Cato J. 26: 159.

Li, Y., and J.C. Beghin. 2014. "Protectionism indices for non-tariff measures: An application to maximum residue levels," Food Policy 45: 57-68.

Mansfield, E.D., and M. L. Busch. 1995. "The Political Economy of Nontariff Barriers: A Cross-National Analysis. ”International Organization, Vol. 49, No. 4 (Autumn): 723749.

Marette, S., and J.C. Beghin. 2010. “Are Standards Always Protectionist?” Review of International Economics Vol. 18 no. 1 (2010): 179-192.

Peterson, E.B., and D. Orden. 2008. "Avocado pests and avocado trade." American Journal of Agricultural Economics 90 (2): 321-335.

Ray, E. J.1981. “The Determinants of Tariff and Nontariff Trade Restrictions in the United States.” Journal of Political Economy Vol. 89, No.1 (Feb): 105-121. 
Rodrik, D. 1995. "The Political Economy of Trade Policy,” in G. Grossman and K. Rogoff (eds.), Handbook of International Economics, vol. 3, Amsterdam, North-Holland, 1995.

Stanton, G.H. 2012. "The WTO dispute settlement framework and operation in Anderson, K., C.F. McRae, and D. W. Wilson, eds. The economics of quarantine and the SPS agreement. University of Adelaide Press.

Swinnen, J.F.M., and T. Vandemoortele. 2009. "Are food safety standards different from other food standards? A political economy perspective." European Review of Agricultural Economics 36 no. 4: 507-523.

Swinnen, J.F.M., A. Olper, and T. Vandemoortele. 2012. "Impact of the WTO on Agricultural and Food Policies.” The World Economy 35(9): 1089-1101.

2011. "The Political Economy of Policy Instrument Choice: Theory and

Evidence from Agricultural Policies.” Licos Discussion Paper 279/2011.

Trefler, D. 1993. "Trade Liberalization and the Theory of Endogenous Protection: An Econometric Study of U.S. Import Policy.” Journal of Political Economy Vol. 101. No. 1: 138-160.

Xiong, B., and J.C. Beghin, J. 2014. "Disentangling Demand-Enhancing and Trade-Cost Effects of Maximum Residue Regulations.” Economic Inquiry 52(3): 1190-1203. 


\section{Appendix A. The list of countries}

Table A. Names of countries, in alphabetical order

\begin{tabular}{llll}
\hline Albania & Cuba & Japan & Russia \\
Algeria & Dominican Rep. & Jordan & Saint Lucia \\
Argentina & Ecuador & Kenya & Singapore \\
Australia & Egypt & Malaysia & South Africa \\
Bahamas & El Salvador & Mexico & Sri Lanka \\
Bangladesh & European Union & Morocco & Taiwan \\
Barbados & Guatemala & New Zealand & Thailand \\
Brazil & Honduras & Nicaragua & Trinidad and Tobago \\
Canada & Hong Kong & Pakistan & Tunisia \\
Chile & India & Panama & Turkey \\
China & Indonesia & Peru & United Arab Emirates \\
Colombia & Israel & Philippines & United States \\
Costa Rica & Jamaica & Rep. of Korea & Venezuela \\
& & & Vietnam \\
\hline
\end{tabular}

Note: * European Union represents the 28 member countries. 


\section{Appendix B. The list of products}

Table B. Names of countries, by chapters of the Harmonized System

\begin{tabular}{ll}
\hline Chapter code and description & Products of this study \\
\hline HS-02: Meat and edible meat offal & $\begin{array}{l}\text { Cattle meat, cattle kidney, cattle liver, other cattle } \\
\text { byproducts, hog meat, hog fat, hog kidney, hog liver, } \\
\text { other hog byproducts, poultry meat, poultry fat, poultry } \\
\text { kidney, poultry liver, other poultry byproducts, sheep } \\
\text { meat, sheep kidney, sheep liver, and other sheep } \\
\text { byproducts. }\end{array}$ \\
\hline
\end{tabular}

HS-04: Dairy produce; bird eggs; $\quad$ Eggs, milk, and milk fat.

natural honey; edible products of

animal origin

HS-06: Live trees and other plants;

Edible canna, chicory roots, chufa, and dasheen corm.

bulbs, roots and the like; cut flowers

and ornamental foliage

HS-07: Edible vegetables and certain Amaranth leafy, arracacha, arrowroot, artichoke, Chinese

roots and tubers

artichoke, Jerusalem artichoke, arugula, asparagus,

Balsam pear, bean, Adzuki bean, broad bean, dried broad bean, succulent broad bean, dried bean, podded edible bean, Kidney bean, Lablab bean, Lima bean, Moth bean, Mung bean, Navy bean, Rice bean, Runner bean, Snap bean, Tepary bean, Urd bean, Yardlong bean, garden beet root, garden beet top, broccoli, Chinese broccoli, Raab Broccoli, Brussels Sprouts, butternut, cabbage, Chinese Bok-Cho cabbage, Chinese Napa cabbage, carrot, cassava leaves, cassava roots, cauliflower, celeriac root, celery, Chinese celery, chervil, Turnip chervil root, chickpea, chicory tops, edible chrysanthemum, collards, corn salad, sweet corn kernels, cowpea, cress, Garden cress, Upland cress, cucumber, dandelion leaves, dock, eggplant, endive, fennel, Florence fresh fennel, garlic, edible, gourd, guar, horseradish, jackbean, kale, kohlrabi, leeks, lentil, leren, lettuce head, lettuce leaf, mizuna, mushroom, mustard greens, mustard spinach, okra, olive, green onion, Welsh onion, onion bulb, orach, turnip-rooted parsley, fresh parsley, parsnip, pea, dried pea, edible podded pea, green pea, Pigeon pea, succulent pea, sugar snap pea, non-bell pepper, pimentos, potato, pumpkin, garden purslane, winter purslane, radish, radish top, green rape, rutabaga root, rutabaga top, salsify root, salsify top, shallots, skirret, spinach, New Zealand spinach, Vine spinach, summer squash, winter squash, sweet potato, Swiss chard, swordbean, tanier, taro, tomato, turnip, turnip top, watercress, yam bean, and true yam tuber. 


\section{Appendix B (continued)}

Table B (continued). Names of countries, by chapters of the Harmonized System

\begin{tabular}{|c|c|}
\hline Chapter code and description & Products of this study \\
\hline $\begin{array}{l}\text { HS-08: Edible fruits and nuts; peel } \\
\text { of citrus fruit or melons }\end{array}$ & $\begin{array}{l}\text { Almond, apple, apricot, avocado, Balsam apple, banana, } \\
\text { beechnut, blackberry, blueberry, boysenberry, } \\
\text { calamondin, cantaloupe, cashew, chayote fruit, cherry, } \\
\text { chestnut, citron citrus, coconut, crabapple, cranberry, } \\
\text { currant, date, dewberry, elderberry, passion fruit, } \\
\text { gooseberry, grape, grapefruit, ground cherry, guava, } \\
\text { hazelnut, honeydew, huckleberry, juneberry, kiwifruit, } \\
\text { kumquat, lemon, lime, loganberry, loquat, mango, melon, } \\
\text { muskmelon, nectarine, Brazil nut, hickory nut, } \\
\text { Macadamia nut, pine nut, papaya, pawpaw, peach, pear, } \\
\text { oriental pear, pecan, pepino, pineapple, pistachio, } \\
\text { plantain, dried plum prune, fresh plum prune, } \\
\text { pomegranate, pomelo, quince, raisin, raspberry, } \\
\text { strawberry, tangelo, tangerine, tomatillo, walnut, } \\
\text { watermelon, and youngberry. }\end{array}$ \\
\hline HS-09: Coffee, tea, mate and spices & Ginger, pepper, and summer savory. \\
\hline HS-10: Cereals & $\begin{array}{l}\text { Barley, corn, corn pop, lupin, pearl millet, proso millet, } \\
\text { oat, rice, sorghum, and wheat. }\end{array}$ \\
\hline $\begin{array}{l}\text { HS-12: Oil seeds and oleaginous } \\
\text { fruits; miscellaneous grains, seeds } \\
\text { and fruits; industrial or medicinal } \\
\text { plants; straw and fodder }\end{array}$ & $\begin{array}{l}\text { Cotton seed, dried hop cones, mustard seed, peanut, } \\
\text { rapeseed, sesame seed, soybean, sugar beet roots, sugar } \\
\text { cane, and sunflower seed. }\end{array}$ \\
\hline $\begin{array}{l}\text { HS-15: Animal or vegetable fats and } \\
\text { oils and their cleavage products } \\
\text { prepared edible fats; animal or } \\
\text { vegetable waxes }\end{array}$ & Cattle fat, hog fat, poultry fat, and sheep fat. \\
\hline
\end{tabular}


Figure 1. Maximum Residue Limit stringency scores across countries and regions

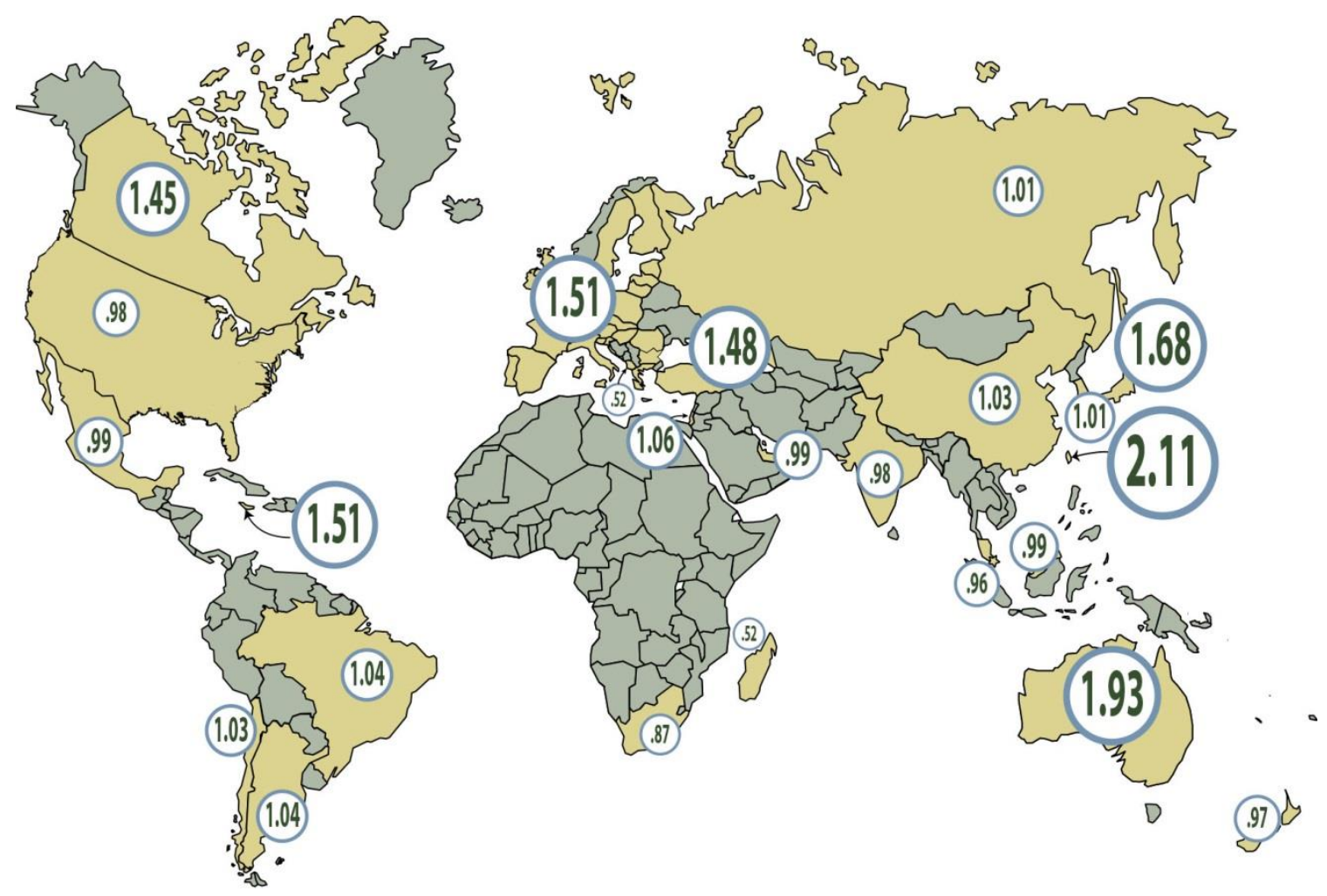

\begin{tabular}{|c|c|c|c|c|c|}
\hline Country & MRL Score & Country & IRL Score & Country & MRL Score \\
\hline Taiwan & 2.11 & Brazil & 1.04 & Mexico & 0.99 \\
\hline Australia & 1.93 & Argentina & 1.04 & United States & 0.98 \\
\hline Japan & 1.68 & Chile & 1.03 & India & 0.98 \\
\hline Jamaica & 1.51 & Russian Federation & 1.03 & New Zealand & 0.97 \\
\hline European Union & 1.51 & Rep. of Korea & 1.01 & Singapore & 0.96 \\
\hline Turkey & 1.48 & China & 1.01 & South Africa & 0.87 \\
\hline Canada & 1.45 & Malaysia & 0.99 & Sri Lanka & 0.52 \\
\hline Israel & 1.06 & Unit. Arab Emirates & 0.99 & Albania & 0.52 \\
\hline
\end{tabular}

Note: European Union represents all 28 member countries. 